\title{
Performance of Barangay Police Security Officer (BPSO) or Tanod in Maintaining Peace and Order
}

\author{
Mary Chris Austria-Cruz
}

Nueva Ecija University of Science and Technology, Philippines

maria_cristi@yahoo.com

\begin{abstract}
The objective of this study was to explore the performance of duties and responsibilities of barangay security police officers. Barangay officials, barangay police or tanod and other constituents participated in the study. Data collected by means of respondents' demographic profile, performance question assessed by their duties and responsibilities. Employing a descriptive-correlated design, significant difference was being explored. Interviews with experienced law enforcers like police personnel and people with reputation were conducted to support and validate findings. Recommendations on enhance training programs for them to efficiently discharge their duties and responsibilities and amendments to honorarium was proposed to compensate the risk and sacrifices of barangay tanods in their service. This study was anchored on the duties and responsibilities that are provided under the Memorandum Circular 2003-42 with the subject "Guidelines on Professionalizing the Barangay Tanod". The researcher tested the hypothesis, "there is no significant difference between the constituents (including tanod) and barangay officials (including barangay councilor and staff) in the perception of the performance of Barangay Police Security Officers or Tanod's duties and responsibilities. The descriptive method of research was used in the conduct of this study, and the use of questionnaire checklist. The statistical used were frequency, percentage distribution mean and t-test. The level of significance was established at 0.05 level.
\end{abstract}

Keywords-Barangay Police Security Officer, Tanod, Peace and Order, Barangay, Duties and Responsibilities.

\section{INTRODUCTION}

Peace and order is an essential ingredient in maintaining economic development, social order and political stability (Bayan, 2011). According to the Local Government Code of 1991, Republic Act No. 7160, the role of the Barangay in assures the peace and order in the barangay level. Pursuant to DILG Memorandum Circular 2003-42, professionalizing these BPSOs ensures that peace and order and public reference to public safety. As the basic political unit, the creation of the Barangay Police Security Officers/ BPSOs, otherwise commonly known as "Barangay Tanods,"security are sustained as the key factor in Barangay's growth. Provided in the DILG's trainers guidebook, the barangay tanod's duties and responsibilities include: assisting barangay officials in crime prevention and promoting public safety through patrolling/"ronda", reporting to the offices concerned of any disruptions or unjust events, tracking the presence and actions of criminals and illegal elements; assisting police and "lupongtagapamayapa" in the execution of warrants and other judicial proceedings; and assisting barangay officials in the enforcement of national and local laws; and other means deemed appropriate in the prevention of crime.

Public safety or its absence, impacts the lives of everyone (Moore \& Braga, 2004). Under NAPOLCOM Memorandum Circular 2008-013, the Barangay Police Security Officers serving as an auxiliary of the Philippine National Police, are considered as force multiplier. Though barangay police or "tanod" works on a voluntary-basis, they do not hesitate to risk their lives just to ensure the security of the people in their respective Barangay (Benitez, 2013).According to De Jesus (2018), Usec. Diño said he would push for a bill that would grant rights for barangay watchmen to receive medical and housing benefits, as well as legal assistance and right to security of tenure.

According to Shoemaker (1996), It is argued that, due to lack of resources, conventional socialization practices and the value of the barangay justice system, juvenile courts and correctional facilities are used less often than the juvenile code would suggest and this situation is likely to continue. Several businesses are already introducing programs to help motivate the public even from the level of barangay, as a way to help curb rising crime incidences (Samaniego, 2015). 
Driven by these foregoing insights, the researchers found it was interesting to assess the barangay police security officer's performance in maintaining peace and order and as an avenue for access of security on the local setting. The researchers conducted the study based on the performance of BPSO duties and responsibilities as provided under the Memorandum Circular 2003-042. Orientation on their duties and task, training program and amendments to honorarium were proposed for the improvement of the Barangay Police Safety Officers level of effectiveness manifested on their individual performance.

\section{CONCEPTUAL FRAMEWORK}

In all aspects of Government exist the social and economic services needed by the people such as benefits, free education, livelihood program, and most importantly, their security and the protection of their individual and community rights. Barangay, being the basic unit of the local government plays an important role in the development of our nation. The status of peace and order in a barangay illuminate that a peaceful barangay is a peaceful country. Peace and order helps in maintain economic development, social order and political stability (Ac Rodriguez 2013).

The researchers conducted the study based on the performance Barangay Police Security Officer's duties and responsibilities as provided under the Memorandum Circular 2003-042. This study focused on the assessment of Barangay Tanods' performance in selected Barangays in Cabanatuan City in terms of their duties and responsibilities operations as provided under Memorandum Circular 2003-042.

III. OBJECTIVES OF THE STUDY

This study described the the performance of Barangay Police Security Officers (BPSOs) or Tanods in terms of the duties

Table 1. Number 1 Duties and Responsibilities of Barangay Police Security Officer (BPSO)

\begin{tabular}{|c|c|c|c|c|}
\hline \multirow[t]{2}{*}{ Item } & \multicolumn{2}{|c|}{$\begin{array}{l}\text { Brgy. Tanod\& } \\
\text { Constituents }\end{array}$} & \multicolumn{2}{|c|}{ Brgy. Officials } \\
\hline & WM & VI & WM & VI \\
\hline $\begin{array}{l}\text { 1. Assist the Barangay Oficials in implementing ordinances and administrative } \\
\text { code of the barangay. }\end{array}$ & 4.91 & A & 4.98 & A \\
\hline $\begin{array}{l}\text { 2. Implement teamwork in preventing or otherwise minimizing the commission } \\
\text { of crime in the barangay. }\end{array}$ & 4.72 & A & 4.96 & A \\
\hline 5. Helps the Barangay Officials prevent crimes and promote peace and order. & 4.67 & A & 4.89 & A \\
\hline Grand Weighted Mean & 4.76 & $\mathbf{A}$ & 4.89 & $\mathbf{A}$ \\
\hline
\end{tabular}

and responsibilities as provided under Memorandum Circular No. 2003-42 and the significant difference between the constituents (including tanod) and barangay officials (including barangay councilor and staff) in the perception of duties and responsibilities of Barangay Police Security Officers or Tanod.

\section{HYPOTHESIS OF THE STUDY}

There is no significant difference between the constituents (including tanod) and barangay officials (including barangay councilor and staff) in the perception of the performance of Barangay Police Security Officers or Tanod's duties and responsibilities.

\section{METHODOLOGY}

The descriptive method of research was used in this study because it involves description, recording, analysis and interpretation of condition that really exists. It is appropriate to use descriptive method in gathering information about the present existing condition (Creswell, 2014). The statistical used were frequency, percentage distribution mean and t-test. The level of significance was established at 0.05 levels.

\section{RESULTS}

Duties and Responsibilities of Barangay Police Security Officers in Accordance with DILG Memorandum Circular No. 2003-042

Based on Table 1 which is Assist the Barangay officials in the prevention of crime and the promotion of public safety is being performed Always (A). 
Based on Table 2 Conduct patrol or "ronda" in the Barangay, by conducting patrol/"ronda" at day time, conducts patrol/ronda at night time, uses their weapon/equipment in times of patrol/ronda and Assist by Brgy.Official in conducting patrol or ronda were being performed Always, and assist by the Brgy.Officials in conducting patrol was being performed Most of the Time (MT)whish assessed by barangay constituents. Barangay Officials' answers under these \#2 duties had a verbal interpretation of being performed Always (A).

Table 2. Number 2 Duties and Responsibilities of Barangay Police Security Officer (BPSO)

\begin{tabular}{|c|c|c|c|c|}
\hline \multirow[t]{2}{*}{ Item } & \multicolumn{2}{|c|}{$\begin{array}{c}\text { Brgy. Tanod\& } \\
\text { Constituents }\end{array}$} & \multicolumn{2}{|c|}{ Brgy. Officials } \\
\hline & WM & VI & WM & VI \\
\hline 1. Conducts patrol/ronda at day time. & 4.43 & A & 4.73 & A \\
\hline 2. Conducts patrol/ronda at night time. & 4.87 & A & 4.89 & A \\
\hline 3. Uses their weapon/equipment in times of patrol/ronda. & 4.84 & A & 4.73 & A \\
\hline 4. Assist by the Brgy.Officials in conducting patrol. & 4.13 & MT & 4.36 & A \\
\hline $\begin{array}{l}\text { 5. Conducts patrolling/ronda even during natural } \\
\text { disasters(calamity and typhoon) }\end{array}$ & 4.64 & A & 4.76 & A \\
\hline Grand Weighted Mean & 4.58 & $\mathbf{A}$ & 4.69 & $\mathbf{A}$ \\
\hline
\end{tabular}

Based on Table 3 Report to the concerned barangay officials or through hotline 117 the occurrence of any crimes, fire, accident, public disturbance and environmental degradation activities and the other untoward incident in the barangay, the barangay constituents and barangay officials' answers had a verbal interpretation of being performed Always.

Table 3. Number 3 Duties and Responsibilities of Barangay Police Security Officer (BPSO)

\begin{tabular}{|cl|c|c|c|c|}
\hline \multicolumn{2}{|c|}{ Item } & \multicolumn{2}{c|}{$\begin{array}{c}\text { Brgy. Tanod\& } \\
\text { Constituents }\end{array}$} & \multicolumn{2}{c|}{ Brgy. Officials } \\
\hline & & WM & VI & WM & VI \\
\hline 1. & Immediately responds to incidents that occur during their duty. & 4.95 & $\mathrm{~A}$ & 4.91 & $\mathrm{~A}$ \\
\hline 2. & $\begin{array}{l}\text { Alert and report to their central units, concerned or through hotline } \\
\text { "117" the incidents taken to their barangay. }\end{array}$ & 4.51 & $\mathrm{~A}$ & 4.73 & $\mathrm{~A}$ \\
\hline 3. & Responds in any natural calamity (typhoon, floods, earthquake) & 4.92 & $\mathrm{~A}$ & 4.93 & $\mathrm{~A}$ \\
\hline 4. & $\begin{array}{l}\text { Assisted by the PNP in responding to riot/rumble taken to their } \\
\text { barangay. }\end{array}$ & 4.58 & $\mathrm{~A}$ & 4.8 & $\mathrm{~A}$ \\
\hline $\begin{array}{l}\text { Reports in authorative (Brgy. Officials, PNP) the alleged and suspected } \\
\text { criminals in their barangay. }\end{array}$ & 4.57 & $\mathrm{~A}$ & 4.89 & $\mathrm{~A}$ \\
\hline & Grand Weighted Mean & $\mathbf{4 . 7 0}$ & $\mathrm{A}$ & $\mathbf{4 . 8 5}$ & $\mathbf{A}$ \\
\hline
\end{tabular}

Based on Table 4Monitor the presence and or activities of suspicious persons, criminals, and other lawless elements within the jurisdiction and report the same to the other proper authorities or through Hotline "117", by monitoring the presence of suspicious persons, criminals, and other lawless elements within the barangay during daytime and night time, implement certain techniques and programs in reducing or to suppress the commission of crime in the barangay, report any information they gathered in monitoring the activities of lawless elements to the authorities, monitors abandoned buildings that may be used for clandestine activities the barangay constituents answers had a verbal interpretation of being performed Always (A) and monitors the activities of suspicious persons, criminals, and other lawless elements within the barangay during daytime and night time, was being performed Most of the Time (MT). The barangay officials however had a different answer or perception on the number 4 duties and responsibilities wherein their assessment is that they were all performed always. 
Table 4. Number 4 Duties and Responsibilities of Barangay Police Security Officer (BPSO)

\begin{tabular}{|c|c|c|c|c|}
\hline \multirow[t]{2}{*}{ Item } & \multicolumn{2}{|c|}{$\begin{array}{c}\text { Brgy. Tanod\& } \\
\text { Constituents }\end{array}$} & \multicolumn{2}{|c|}{ Brgy Officials } \\
\hline & WM & VI & WM & VI \\
\hline $\begin{array}{l}\text { 1. Monitors the presence of suspicious persons, criminals, and other } \\
\text { lawless elements within the barangay during daytime and night } \\
\text { time. }\end{array}$ & 4.52 & A & 4.58 & A \\
\hline $\begin{array}{l}\text { 2. Monitors the activities of suspicious persons, criminals, and other } \\
\text { lawless elements within the barangay during daytime and night } \\
\text { time. }\end{array}$ & 3.97 & MT & 4.2 & A \\
\hline $\begin{array}{l}\text { 3. Implement certain techniques and programs in reducing or to } \\
\text { suppress the commission of crime in the barangay. }\end{array}$ & 4.54 & A & 4.73 & A \\
\hline $\begin{array}{l}\text { 4. Report any information they gathered in monitoring the activties } \\
\text { of lawless elements to the authorities. }\end{array}$ & 4.4 & A & 4.78 & A \\
\hline $\begin{array}{l}\text { 5. Monitors abandoned buildings that may be used for clandestine } \\
\text { activities. }\end{array}$ & 4.51 & A & 4.69 & A \\
\hline Grand Weighted Mean & 4.39 & $\mathbf{A}$ & 4.60 & $\mathbf{A}$ \\
\hline
\end{tabular}

Based on Table 5 Conducts surveillance on crime breeding areas within the barangays/puroks, the investigate suspicious places and activities, observe people clandestinely and reports any observation/findings they gathered to the proper authorities or through the Hotline "117", the barangay constituents answers had a verbal interpretation of being performed Always (A) were being performed Always and visiting houses and place of works was being performed Most of the Time (MT). The barangay officials' answers under \#5 Duties and Responsibilities of Barangay Police Security Officers or Tanod has a verbal interpretation as being performed Always (A).

Table 5. Number 5 Duties and Responsibilities of Barangay Police Security Officer (BPSO)

\begin{tabular}{|c|c|c|c|c|}
\hline \multirow[t]{2}{*}{ Item } & \multicolumn{2}{|c|}{$\begin{array}{c}\text { Brgy. Tanod\& } \\
\text { Constituents }\end{array}$} & \multicolumn{2}{|c|}{ Brgy. Officials } \\
\hline & WM & VI & WM & VI \\
\hline 1. Visits houses and place of works. & 3.97 & MT & 4.22 & A \\
\hline $\begin{array}{l}\text { 2. Conducts surveillance on crime breeding areas within the } \\
\text { barangays/puroks. }\end{array}$ & 4.64 & A & 4.71 & A \\
\hline 3. Investigate suspicious places and activities. & 4.50 & A & 4.62 & A \\
\hline 4. Observe people clandestinely. & 4.49 & A & 4.67 & A \\
\hline $\begin{array}{l}\text { 5. Reports any observation/findings they gathered to the } \\
\text { proper authorities or through the Hotline " } 117 \text { " }\end{array}$ & 4.31 & A & 4.78 & A \\
\hline Grand Weighted Mean & 4.38 & $\mathbf{A}$ & 4.60 & $\mathbf{A}$ \\
\hline
\end{tabular}

Based on Table 6 Assist the police and the "LupongTagapamayapa" in the execution of warrants and other judicial processes such as tracking the whereabouts of missing persons, in arresting escaped prisoners and other fugitives from justice, and in the recovery of stolen properties, the barangay constituents and barangay officials answers had a verbal interpretation of being performed Always (A) except this item which is Assist the police in arresting escaped prisoners and other fugitives from justice within their jurisdiction, was being performed Most of the Time (MT). 
Table 6. Number 6 Duties and Responsibilities of Barangay Police Security Officer (BPSO)

\begin{tabular}{|c|c|c|c|c|}
\hline \multirow[t]{2}{*}{ Items } & \multicolumn{2}{|c|}{$\begin{array}{l}\text { Brgy. Tanod\& } \\
\text { Constituents }\end{array}$} & \multicolumn{2}{|c|}{ Brgy. Officials } \\
\hline & WM & VI & WM & VI \\
\hline $\begin{array}{l}\text { 1. Assist the police and the LupongTagapamayapa in the execution of } \\
\text { warrants within the barangay. }\end{array}$ & 4.83 & A & 4.87 & A \\
\hline 2. Helps the police in tracking the whereabouts missing persons. & 4.85 & A & 4.67 & $\mathrm{~A}$ \\
\hline $\begin{array}{l}\text { 3. Assist the police in arresting escaped prisoners and other fugitives } \\
\text { from justice within their jurisdiction. }\end{array}$ & 4.09 & MT & 4.04 & MT \\
\hline $\begin{array}{l}\text { 4. Assists the police and LupongTagapamayapa in recovering stolen } \\
\text { properties in their barangay. }\end{array}$ & 4.78 & A & 4.82 & A \\
\hline $\begin{array}{l}\text { 5. Assisting the police and the LupongTagapamayapa in all other } \\
\text { judicial processes. }\end{array}$ & 4.78 & A & 4.58 & A \\
\hline Grand Weighted Mean & 4.64 & A & 4.60 & A \\
\hline
\end{tabular}

Based on Table 7 Coordinates closely with the Barangay Officials and police/local authorities in the drive against all forms of crime such as terrorism, smuggling car napping, drug trafficking, drug pushing, illegal gambling, child abuse, crimes against women, all forms of vices and syndicated crimes, were being performed Always (A).

Table 7. Number 7 Duties and Responsibilities of Barangay Police Security Officer (BPSO)

\begin{tabular}{|c|c|c|c|c|}
\hline \multirow[t]{2}{*}{ Item } & \multicolumn{2}{|c|}{$\begin{array}{c}\text { Brgy. Tanod\& } \\
\text { Constituents }\end{array}$} & \multicolumn{2}{|c|}{ Brgy. Officials } \\
\hline & WM & VI & WM & VI \\
\hline $\begin{array}{l}\text { 1. Coordinates closely with the barangay officials and police/local } \\
\text { authorities in the drive against terrorism, smuggling and } \\
\text { carnapping. }\end{array}$ & 4.84 & A & 4.78 & A \\
\hline $\begin{array}{l}\text { 2. Coordinates closely with the barangay officials and police/local } \\
\text { authorities in the drive against drug trafficking and drug pushing. }\end{array}$ & 4.85 & A & 4.64 & A \\
\hline $\begin{array}{l}\text { 3. Coordinates closely with the barangay officials and police/local } \\
\text { authorities in the drive against illegal gambling. }\end{array}$ & 4.70 & A & 4.6 & $\mathrm{~A}$ \\
\hline $\begin{array}{l}\text { 4. Coordinates closely with the barangay officials and police/local } \\
\text { authorities in the drive against child abuse and crimes against } \\
\text { women. }\end{array}$ & 4.81 & A & 4.87 & A \\
\hline $\begin{array}{l}\text { 5. Coordinates closely with the barangay officials and police/local } \\
\text { authorities in the drive against all other forms of vices and } \\
\text { syndicated crimes. }\end{array}$ & 4.84 & A & 4.82 & A \\
\hline Grand Weighted Mean & 4.81 & $\mathbf{A}$ & 4.74 & $\mathbf{A}$ \\
\hline
\end{tabular}

Based on Table 8, it implies from constituents (including barangay councilor) that under this item which is Assist in the institutionalization of PATROL "117" Program, subitems Assisting the institutionalization of Patrol 117 program, every constituents aware that there is a program PATROL 117 for assistance or emergency, and Active radio frequency or is reachable when calling, were being performed Most of the Time (MT) and uses of two-way radio, cellular phone or telephones as a means of communication and have an available two-way radio or phones on their pocket to be used when confronted with emergency, were being performed Always (A). Barangay officials answers on the item which is Assist in the institutionalization of Patrol 117 program, that they are aware that there is a program PATROL 117 for assistance or emergency, Uses of two-way radio, cellular phone or 
telephones as a means of communication and item number and Have an available two-way radio or phones on their pocket to be used when confronted with emergency were being performed Always (A) and under item Active radio frequency or is reachable when calling were being performed Most of the Time.

Table 8.Number 8 Duties and Responsibilities of Barangay Police Security Officer (BPSO)

\begin{tabular}{|c|c|c|c|c|}
\hline \multirow[t]{2}{*}{ Item } & \multicolumn{2}{|c|}{$\begin{array}{l}\text { Brgy. Tanod\& } \\
\text { Constituents }\end{array}$} & \multicolumn{2}{|c|}{ Brgy Officials } \\
\hline & WM & VI & WM & VI \\
\hline 1. Assist in the institutionalization of Patrol 117 program. & 4.13 & MT & 4.33 & $\mathrm{~A}$ \\
\hline $\begin{array}{l}\text { 2. Everyone is aware that there is a program PATROL } 117 \text { for } \\
\text { assistance or emergency. }\end{array}$ & 3.98 & MT & 4.29 & A \\
\hline $\begin{array}{l}\text { 3. Uses of two-way radio, cellular phone or telephones as a means of } \\
\text { communication. }\end{array}$ & 4.86 & A & 4.78 & A \\
\hline $\begin{array}{l}\text { 4. Have an available two-way radio or phones on their pocket to be } \\
\text { used when confronted with emergency. }\end{array}$ & 4.76 & A & 4.67 & A \\
\hline 5. Active radio frequency or is reachable when calling. & 3.90 & MT & 4.02 & MT \\
\hline Grand Weighted Mean & 4.33 & $\mathbf{A}$ & 4.42 & $\mathbf{A}$ \\
\hline
\end{tabular}

Based on Tables 9 to 12, these items which Assist in the implementation of the Fire Code of the Philippines, Detects of all forms of fire hazards and other public safety hazards/violation and to institute corrective measures within his capability, Assist in facilitating smooth flow of traffic, and Perform other functions as may be directed by the Punong Barangay were being performed Always (A) as assessed by both the barangay constituents and barangay officials.

Table 9. Number 9 Duties and Responsibilities of Barangay Police Security Officer (BPSO)

\begin{tabular}{|c|c|c|c|c|}
\hline \multirow[t]{2}{*}{ Item } & \multicolumn{2}{|c|}{$\begin{array}{c}\text { Brgy. Tanod\& } \\
\text { Constituents }\end{array}$} & \multicolumn{2}{|c|}{ Brgy. Officials } \\
\hline & WM & VI & WM & VI \\
\hline $\begin{array}{l}\text { 1. Assist the BFP in the implementation of fire code of the } \\
\text { Philippines. }\end{array}$ & 4.52 & A & 4.49 & A \\
\hline $\begin{array}{l}\text { 2. Coordinates with the BFP in conducting program regarding the } \\
\text { Fire Code of the Philippines in the barangay }\end{array}$ & 4.55 & A & 4.51 & A \\
\hline 3. Undergo training on fire suppression. & 4.41 & $\mathrm{~A}$ & 4.71 & $\mathrm{~A}$ \\
\hline 4. Undergo training in emergency response. & 4.66 & $\mathrm{~A}$ & 4.47 & $\mathrm{~A}$ \\
\hline $\begin{array}{l}\text { 5. Undergo training that includes fire suppression strategies, } \\
\text { tactics, techniques and the use of portable fire extinguisher and } \\
\text { other equipment. }\end{array}$ & 4.41 & A & 4.8 & A \\
\hline Grand Weighted Mean & 4.51 & $\mathbf{A}$ & 4.60 & $\mathbf{A}$ \\
\hline
\end{tabular}

Table 10. Number 10 Duties and Responsibilities of Barangay Police Security Officer (BPSO)

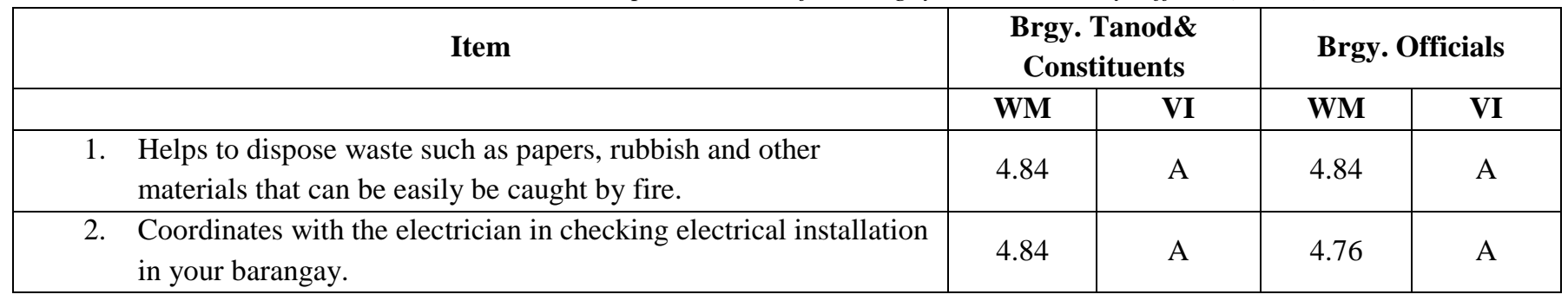


3. Prepare in case of assisting the BFP on fire suppression in their barangay.

4. Helps to detect and dangerous weapon that causes hazards in public safety within the barangay.

5. Detect any forms of violation that causes hazards in public safety.

\begin{tabular}{|l|l|l|l|}
\cline { 3 - 4 } 4.73 & $\mathrm{~A}$ & 4.73 & $\mathrm{~A}$ \\
\hline 4.69 & $\mathrm{~A}$ & 4.71 & $\mathrm{~A}$ \\
\hline 4.80 & $\mathrm{~A}$ & 4.8 & $\mathrm{~A}$ \\
\hline $\mathbf{4 . 7 8}$ & $\mathbf{A}$ & $\mathbf{4 . 7 7}$ & $\mathrm{A}$ \\
\hline
\end{tabular}

Table 11. Number 11 Duties and Responsibilities of Barangay Police Security Officer (BPSO)

\begin{tabular}{|c|c|c|c|c|}
\hline \multirow[t]{2}{*}{ Item } & \multicolumn{2}{|c|}{$\begin{array}{l}\text { Brgy. Tanod\& } \\
\text { Constituents }\end{array}$} & \multicolumn{2}{|c|}{ Brgy. Officials } \\
\hline & $\mathbf{W M}$ & VI & WM & VI \\
\hline $\begin{array}{l}\text { 1. Coordinates with the police in maintaining a smooth flow of } \\
\text { traffic. }\end{array}$ & 4.90 & A & 4.73 & A \\
\hline 2. Help to reduce the traffic in fiesta. & 4.83 & A & 4.76 & A \\
\hline 3. Helps in directing traffic when there is an internment. & 4.89 & A & 4.96 & A \\
\hline 4. Assist the traffic in times of having a parade in barangay & 4.79 & A & 4.76 & A \\
\hline 5. Assist the traffic in any program or activities in the barangay. & 4.94 & A & 4.91 & A \\
\hline Grand Weighted Mean & 4.81 & $\mathbf{A}$ & 4.82 & $\mathbf{A}$ \\
\hline
\end{tabular}

Table 12.Number 12 Duties and Responsibilities of Barangay Police Security Officer (BPSO)

\begin{tabular}{|l|l|l|}
\hline t-Test: Two-Sample Assuming Unequal Variances & $\begin{array}{l}\text { BARANGAY TANOD } \\
\text { \& CONSTITUENTS }\end{array}$ & BRGY. OFFICIALS \\
\hline Mean & 4.636944444 & 4.704814815 \\
\hline Variance & 0.066868679 & 0.075707825 \\
\hline Observations & 105 & 45 \\
\hline Hypothesized Mean Difference & 0 & \\
\hline Df & 79 & \\
\hline t Stat & -1.409312521 & \\
\hline P(T<=t) one-tail & 0.081333567 & \\
\hline t Critical one-tail & 1.664371409 & \\
\hline P(T<=t) two-tail & 0.162667134 & \\
\hline t Critical two-tail & 1.99045021 & \\
\hline
\end{tabular}

By using t-Test: Two-Sample Assuming Unequal Variance, the results obtained shows that the critical value (1.99) are greater than the computed values (-1.40). it indicates that the hyphotesis was accepted, therefore it reveals that there exist no significant difference between the constituents (including tanod) and barangay officials (including barangay councilor and staff) in their perception of the performance of Barangay Police Security Officers or Tanod's duties and responsibilities.

Table 13. T-test Values of performance of duties and responsibilities of Barangay Police Security Officers.

\begin{tabular}{|c|c|c|c|c|}
\hline \multirow[t]{2}{*}{ Item } & \multicolumn{2}{|c|}{$\begin{array}{l}\text { Brgy. Tanod\& } \\
\text { Constituents }\end{array}$} & \multicolumn{2}{|c|}{ Brgy. Officials } \\
\hline & WM & VI & WM & $\overline{\mathrm{VI}}$ \\
\hline $\begin{array}{l}\text { 1. Carry other basic security functions under the supervision of the } \\
\text { Brgy. Captain. }\end{array}$ & 4.96 & $\bar{A}$ & 4.89 & $\bar{A}$ \\
\hline $\begin{array}{l}\text { 2. Assist the Brgy. Captain in the implementation of national and } \\
\text { local laws. }\end{array}$ & 4.89 & A & 4.87 & A \\
\hline
\end{tabular}




\begin{tabular}{|l|l|l|l|l|l|}
\hline 3. & Available to respond in any emergency order of the Brgy. Captain. & 4.92 & $\mathrm{~A}$ & 4.91 & $\mathrm{~A}$ \\
\hline $\begin{array}{l}\text { 4. } \\
\begin{array}{l}\text { Performs the function of maintaining the desirable and balance } \\
\text { environmental through the direction of Punong Barangay. }\end{array}\end{array}$ & 4.90 & $\mathrm{~A}$ & 4.84 & $\mathrm{~A}$ \\
\hline $\begin{array}{l}\text { 5. } \\
\text { Performs other functions as may be directed by the Punong } \\
\text { Barangay. }\end{array}$ & 4.89 & $\mathrm{~A}$ & 4.87 & $\mathrm{~A}$ \\
\hline Grand Weighted Mean & 4.91 & $\mathrm{~A}$ & 4.88 & $\mathrm{~A}$ \\
\hline
\end{tabular}

\section{CONCLUSION AND DISCUSSION}

The performance of barangay police security officer of their duties and responsibilities as enumerated in accordance under DILG MC No. 2003-042; Under the first duties and responsibilities of barangay tanodwere being performed Always (A)as assessed by the barangay constituents and barangay officials. Second, 4 out of 5 enumerated sub items were described as being performed Always (A) and 1 out of 5 was performed Most of the Time (MT). 5 out of 5 enumerated sub items were described as being performed Most of the Time (MT). The \#3 duties and responsibilities of barangay tanod, assesses by the barangay constituents and barangay officials were being performed Always (A). Under the fourth duties and responsibilities of barangay tanod, barangay constituents answers implies that 4 out 5 enumerated sub items were described as being performed Always (A) and 1 out of 5 was performed Most of the Time (MT) while barangay officials answers implies that this item were being performed Always (A). Number 5 duties and responsibilities of barangay tanod, shows that 4 out 5 enumerated sub items were described as being performed Always (A) and 1 out of 5 was performed Most of the Time (MT) while barangay officials' answers under this item had a verbal interpretation as being performed Always (A). Under \#6 duties and responsibilities of barangay tanod, wherein the constituents'answered that in 4 out of 5 enumerated sub items were being performed Always (A) and 1 out of 5 which described as being performed Most of the Time (M). Under the number 8 duties and responsibilities of barangay tanod,barangay constituents answered on 2 out 5 enumerated sub items having a verbal interpretation of being performed Always (A) and 3 out of 5 were being performed Most of the Time (MT), while the barangay officials answered on 4 out 5 enumerated sub items had a verbal interpretation as being performed Always (A) and 1 out 5 enumerated sub items were described being performed most of the Time (MT). The\#9 to \#12 duties and responsibilities of barangay tanod were being performed Always (A) as assessed by both the barangay officials and constituents. Using "T-test twosample assuming unequal variance", as the statistical treatment in the study, the results show that there exists no significant difference between the constituents (including tanod) and barangay officials (including barangay councilor and staff) in the perception of the performance of Barangay Police Security Officers or Tanod's duties and responsibilities.

\section{REFERENCES}

[1] Bayan, Neri (2011, February 24). "The Barangay Tanod System". Sun.Star Retrieved from: http://www.sunstar.com.ph/baguio/opinion/bayan-barangaytanod-system

[2] Benitez, Abegail. B. (2013). Bill gives barangay tanod's kids 50\% discount in tuition in SUCs. Retrieved from: http://www.remate.ph/2013/08/bill-gives-barangay-tanods-kids50-discount-in-tuition-in-sucs/

[3] Creswell, J. W. (2014). A concise introduction to mixed methods research. SAGE publications.

[4] De Jesus(2018). Usec. Diño wants security of tenure for barangay chairmen, watchmen. Philippine Daily Inquirer. Retrieved from: https://newsinfo.inquirer.net/959305/usec-dino-wants-security-oftenure-for-barangay-chairmen-watchmen-martin-dino-dilgundersecretary-barangay-magna-carta

[5] DILG Memorandum Circular 2003-42. Guidelines on Professionalizing the Barangay Tanod. Retrieved from: http://DILG.memorandum.circular.2003-42/pdf

[6] Moore, M. H., \& Braga, A. A. (2004). Police performance measurement: A normative framework. Criminal justice ethics, 23(1), 3-19.

[7] Samaniego, T. S. (2015). Globe helps gov't create sustainable and resilient communities. Philippine Daily Inquirer. Retrieved from: https://business.inquirer.net/202466/globe-helps-govt-createsustainable-and-resilient-communities

[8] Shoemaker, D. J. (1996). Juvenile corrections in the Philippines: the barangay system. Journal of Offender Rehabilitation, 24(1-2), 39-52.

[9] The Local Government Code of 1991. Retrieved from: http://www.local.gov.codeof1991./pdf

[10] NAPOLCOM Memorandum Circular 2008-013. Prescribing Guidelines and Procedures Governing the Deputation of Barangay Tanods as Members of Police Auxiliary Units (PAUs) and Authorizing the Deployment of Pnp Uniformed Personnel to Act as Supervisor of PAU Members. Retrieved from: https://www.napolcom.gov.ph/images/pdf/mc\%202008-013.pdf 